\title{
High molecular mass proteomics analyses of left ventricle from rats subjected to differential swimming training
}

Luiz A O Rocha ${ }^{1,5}$, Bernardo A Petriz ${ }^{1}$, David H Borges ${ }^{1}$, Ricardo J Oliveira ${ }^{2}$, Rosangela V de Andrade ${ }^{1}$, Gilberto B Domont ${ }^{4}$, Rinaldo W Pereira ${ }^{1,2}$ and Octávio L Franco ${ }^{1,3,5^{*}}$

\begin{abstract}
Background: Regular exercises are commonly described as an important factor in health improvement, being directly related to contractile force development in cardiac cells.

In order to evaluate the links between swimming exercise intensity and cardiac adaptation by using high molecular mass proteomics, isogenic Wistar rats were divided into four groups: one control (CG) and three training groups ( $\left(G^{\prime}\right.$ 's), with low, moderate and high intensity of exercises.

In order to evaluate the links between swimming exercise intensity and cardiac adaptation by using high molecular mass proteomics, isogenic Wistar rats were divided into four groups: one control (CG) and three training groups (TG's), with low, moderate and high intensity of exercises.
\end{abstract}

Results: Findings here reported demonstrated clear morphologic alterations, significant cellular injury and increased energy supplies at high exercise intensities. a-MyHC, as well proteins associated with mitochondrial oxidative metabolism were shown to be improved. a-MyHC expression increase 1.2 fold in high intensity training group when compared with control group. a-MyHC was also evaluated by real-time PCR showing a clear expression correlation with protein synthesis data increase in 8.48 fold in high intensity training group. Other myofibrillar protein, troponin , appear only in high intensity group, corroborating the cellular injury data. High molecular masses proteins such as MRS2 and NADH dehydrogenase, involved in metabolic pathways also demonstrate increase expression, respectily 1.5 and 1.3 fold, in response to high intensity exercise.

Conclusions: High intensity exercise demonstrated an increase expression in some high molecular masses myofibrilar proteins, a-MyHC and troponin. Furthermore this intensity also lead a significant increase of other high molecular masses proteins such as MRS2 and NADH dehydrogenase in comparison to low and moderate intensities. However, high intensity exercise also represented a significant degree of cellular injury, when compared with the individuals submitted to low and moderate intensities.

Keywords: Heart tissue, High molecular mass proteomic, Muscle, Myofibrillar proteins, Swimming training

\footnotetext{
* Correspondence: ocfranco@pos.ucb.br

${ }^{1}$ Centro de Análises Proteômicas e Bioquímicas, Programa de Pós-Graduação em Ciências Genômicas e Biotecnologia, Universidade Católica de Brasília, Brasília-DF, Brazil

${ }^{3}$ Departamento de Biologia, Universidade Federal de Juiz de Fora, Juiz de Fora-MG, Brazil

Full list of author information is available at the end of the article
}

\section{Biomed Central}

(c) 2012 Rocha et al.; licensee BioMed Central Ltd. This is an Open Access article distributed under the terms of the Creative Commons Attribution License (http://creativecommons.org/licenses/by/2.0), which permits unrestricted use, distribution, and reproduction in any medium, provided the original work is properly cited. 


\section{Background}

The adaptation is a dynamic process with involvement of many circumstances and is an important life mechanism. The cardiac cells of mammals are submitted to a growth phase after birth maturation period defied as cardiac hypertrophy which is characterized by $\mathrm{n}$ increase in individual size of the cardiomyocyties without cell division. This pattern of hypertrophy development can be initiated in response to some intrinsic and extrinsic stimuli such mechanical stress, neurohumoral factor, cytokines, ischemia and endocrine disorders $[1,2]$.

These stimuli for heart hypertrophy can be divided in "physiological" cardiac hypertrophy, when is result of exercise for example and "pathological" cardiac hypertrophy, which is associated with cardiovascular diseases [1,2]. The physiological hypertrophy has been classified as a positive increase in heart mass, associated with structural remodeling of components of the ventricular walls to support increase in myocyte size, angiogenesis and changes in fibrilar collagen content and organization, whose enhancer the cardiac pump function.

The cellular and molecular bases behind heart adaptations to exercise are not completely understood, but it is believed that a number of cellular adaptations, intrinsic to the cardiomyocyte, are largely responsible for these changes. The mechanism proposed for this structural adaptation is hypertrophy by increase in functional load [3]. This overload is followed by modifications in the gene expression pattern, activation of signaling pathways which included up regulation in the contractile protein synthesis and his organization into sarcomeric units [1-3]. However, it is not clear what role is played by the impact of differing training intensities on the physiological heart muscle's adaptation, in terms of molecular changes.

In summary the literature describes that one of the most important benefits of exercise, associated to cardiocirculatory system consists in the enhancing of heart work efficiency due to contractile capacity increase. Thus, this study aims to verify the rat cardiac muscle adaptation under different intensities of swimming exercise, focusing on high molecular mass proteomics of $R$. novergicus.

\section{Results and discussion}

Measured average values showed a lower lactate accumulation, of $4.6\left( \pm 0.7 \mathrm{mmol} . \mathrm{L}^{-1}\right.$ in $\mathrm{TG}_{3}$ in comparison to $5.9 \pm 0.4 \mathrm{mmol} . \mathrm{L}^{-1}$ in CG). The two other TG's (data not shown) also showed lower value, [4]. Cardiac fibers from left ventricle of rats in the CG showed a normal size and shape (Additional file 1: Figure S1). Similar data were obtained from left ventricle histological sectioning of rats from $\mathrm{TG}_{1}$ (Additional file 1: Figure S1), demonstrating no structural alteration in the heart tissue, which indicated lower hypertrophy. Exercise training was also able to induce heart morphological alterations not seen in the untrained group. The small nucleus presented a rounded or in some cases slightly oval shape, indicating no clear pathological alteration which lower hypertrophy. A few morphologic alterations, such as a small sclerotic area with infiltration of granule lipofuscin, characterizing particular metabolic alterations, probably associated with overload were seen in $\mathrm{TG}_{2}$, (Additional file 1: Figure S1) [5,6]. This pigment is closely associated with oxygen-derived free radicals, which are an important component of muscle fatigue [7] indicating that $\mathrm{TG}_{2}$ are inducing heart tissue modifications to the detriment of improvement in metabolism. On the other hand, microscopic morphology analysis in $\mathrm{TG}_{3}$ indicated cellular hypertrophy, showing several modifications such as several areas with increased fibrosis (Additional file 1: Figure S1), evidencing a higher adaptation to exercise overload. This increase suggests that this level of physical activity was stressful to the heart $[8,9]$. The relative exercise overload is directly associated with oxygen consumption $\left(\mathrm{VO}_{2 \text { máx }}\right)[10,11]$, because mitochondria are strictly involved in the activation of super-oxide synthesis cascade. It is also worth noting that $\mathrm{TG}_{3}$ showed an extended area with necrosis and the presence of leucocytes, probably supporting hypertrophy by replacing dead cells with satellite cells (Additional file 1: Figure S1) [12,13]. One important route to hypertrophy of the myocardium directly involves fibroblast proliferation, which stimulates collagen synthesis[14-16]. Increased collagen content is commonly observed with overload pressure and, in certain cases, may negatively impact both diastolic and systolic function [17]. One of the most important benefits of exercise in the cardio-circulatory system is associated with an increase in circulation capability. This upgrade is strictly dependent on contraction increase, carried out by the expression of different heart myosin isoforms [18-22], which will be described below.

\section{Differential electrophoretic analyses of sedentary and exercise-trained cardiac muscle}

Since exercise-trained groups showed clear heart tissue alterations, SDS-PAGE was conducted in order to evaluate protein expression modification, showing an apparent quantitative increase in $\alpha-\mathrm{MyHC}$ (higher band) and $\beta$-MyHC (lower band) expression (Additional file 2: Figure $\mathrm{S} 2$ ), in $\mathrm{TG}_{2}$ and $\mathrm{TG}_{3}$ compared to CG. Analyzing overlapped images, it was observed that $\alpha-\mathrm{MyHC}$ (Figure 1) increased 1 fold in swimming-trained heart. In order to improve these data, increasing accuracy and leading to an overview of physiologic modifications during swimming exercise training, two-dimensional gels were run by using left ventricles from control and training groups (Additional file 3: Figure S3). Bionumerics ${ }^{\mathrm{TM}}$ from Applied Maths matched 177 spots in the 2-DE control group. 


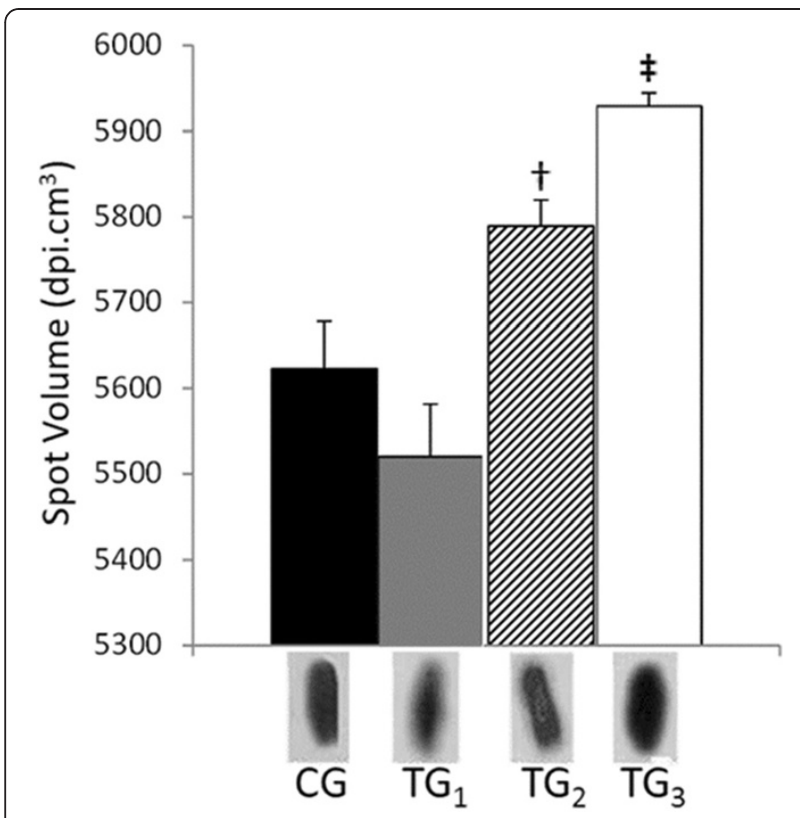

Figure 1 a-MyHC protein quantity analyses. The a-MyHC expression was evaluated by high molecular mass 2-DE technique in rat cardiomyocytes of the left ventricle. CG corresponds to control group; $\mathrm{TG}_{1} ; \mathrm{TG}_{2}$ and $\mathrm{TG}_{3}$ correspond respectively to $2.5 ; 5.0$ and 7.5 to training groups. Different spots volumes are determinate by using software Bionumerics ${ }^{\mathrm{TM}}$. Symbols $†$ and $\ddagger$ represent the statistical difference between respectively $T_{2}$ and $T_{3}$. Statistical analyses were performed by ANOVA $(P<0.05)$. All studies were performed in triplicate.

It is known that two MyHC isoforms, $\alpha-\mathrm{MyHC}$ and $\beta$-MyHC, are expressed in cardiac tissue, and their proportion (normally $\sim 70 \% \alpha-\mathrm{MyHC}$ and $30 \% \beta-\mathrm{MyHC}$ ) in the rodent myocardium directly influences heart power output $[23,24]$. Data reported here are consistent with previous results in which $\mathrm{MyHC}$ was up regulated in exercise-trained rat hearts [11]. Otherwise, these data contradict those observed during moderate exercise training on skeletal rat muscle suffering chronic heart failure [25]. In this case, $\mathrm{MyHC}$ distributions were similar in both groups and training did not alter the $\mathrm{MyHC}$ distribution.

We found 162 spots in $\mathrm{TG}_{1}, 168$ in $\mathrm{TG}_{2}$ and 186 in $\mathrm{TG}_{3}$. The number of spots observed in each gel (Table 1), was lower than previously observed in rat heart protein maps (624 spots) submitted to intensity-controlled endurance exercise [11]. This variation could be explained by a different 2-DE technique here utilized, which is focused on evaluation of high molecular mass proteins ranging from 50-220 kDa, while Burninston [11] evaluated most abundant proteins from $14-116 \mathrm{kDa}$. The average coefficient of variation for normalized spot volume gave $R^{2}=0.82$ for biological and 0.94 for technical replicates, showing reliable gel reproducibility. These values are close to the range reported for technical variation for proteomic analyses of muscle homogenate, including skeletal and heart muscle tissues $[4,11,26]$. Moreover, the average coefficient of variation calculated to compare gels from different groups $\left(\mathrm{CG}, \mathrm{TG}_{1}, \mathrm{TG}_{2}\right.$ and $\mathrm{TG}_{3}$ ) showed a $\mathrm{R}^{2}$ lower than 0.43 , demonstrating the obvious differences in protein maps from rat left ventricles submitted to diverse intensities of training. These proportions were similar to that observed by Burniston [11], evaluating the adaptation of rat cardiac muscle to endurance exercise, despite the different methodologies utilized. While Burniston described the evaluation of proteins from 14 to $116 \mathrm{kDa}$ [27], Our work evaluated proteins varying from 53 to $230 \mathrm{kDa}$, indicating that protein expression behavior in response of exercise is independent of molecular masses. Moreover, these data are only in agreement with protein maps from rat skeletal muscle [4] and human heart [28]. Furthermore, as previously observed in several reports $[4,11]$, some gene products were identified as multi-spot series exhibiting similar molecular masses but different pI, which may indicate unusual splice variants or states of post-translational modification.

\section{Mass spectrometry protein identification}

Of all spots founded seventeen had been considered differentially expressed after swimming training, whereas increase more than one fold and appear in every gel in triplicate. Those were identified by PMF (Table 1) with molecular masses above $56 \mathrm{kDa}$. These data revealed that the majority (27\%) of identified proteins were mitochondrial, one-quarter associated with membrane/

Table 1 MALDI ToF protein identification

\begin{tabular}{|c|c|c|c|c|c|}
\hline Samples & $\begin{array}{l}\text { a-MyHC } \\
\text { average } \\
C_{T}\end{array}$ & $\begin{array}{l}\text { 18srRNA } \\
\text { average } \\
\mathrm{C}_{\mathrm{T}}\end{array}$ & $\Delta \mathrm{C}_{\mathrm{T}}$ & $\Delta \Delta C_{T}$ & $\begin{array}{l}\text { a-MyHC expression } \\
\text { increase in TGs fold related to CG }\end{array}$ \\
\hline Control & $26.31 \pm 0.12$ & $15.21 \pm 0.55$ & $11.10 \pm 0.32$ & $0.00 \pm 0.32$ & $1.00(0.80-1.25)$ \\
\hline $\mathrm{TG}_{1}$ & $25.58 \pm 0.10$ & $15.16 \pm 0.46$ & $10.42 \pm 0.27$ & $-0.68 \pm 0.27$ & $1.60(1.33-1.94)$ \\
\hline $\mathrm{TG}_{2}$ & $25.32 \pm 0.06$ & $15.39 \pm 0.56$ & $9.92 \pm 0.32$ & $-1.18 \pm 0.32$ & $2.26(1.81-2.83)$ \\
\hline $\mathrm{TG}_{3}$ & $26.28 \pm 0.04$ & $18.26 \pm 0.63$ & $8.02 \pm 0.36$ & $-3.08 \pm 0.36$ & 8.48 (6.59-10.91) \\
\hline
\end{tabular}

Real time PCR evaluating fold change expression of ?-MyHC RNA from training groups (TGs) related to untrained group (CG) calculated by $\triangle \Delta C T$ method. Values were presented as a means \pm standard deviation. 
extracellular (25\%), one-quarter myofibrillar/cytoskeletal (25\%) and $23 \%$ associated with different functions such as hystocompatibility (Table 1). Besides the evidence, based on protein analysis, of increased expression of $\alpha-\mathrm{MyHC}$ in our training groups, we decided to corroborate it using mRNA expression (Table 2). Data here reported showed that training intensity is an important factor for $\alpha-\mathrm{MyHC}$ expression. Training groups with overload of $2.5\left(\mathrm{TG}_{1}\right)$ and $5 \%\left(\mathrm{TG}_{2}\right)$ showed increased expression of $\alpha-\mathrm{MyHC}$ related to untrained group (CG). Respectively, these were increases of 1.60 and 2.26 fold in $\alpha$-MyHC expression. However, taking in account standard deviation, the increase in $\mathrm{TG}_{1}$ was 1.33-1.94 and in $\mathrm{TG}_{2}$ it was 1.81-2.83-fold. The overlap in the upper limit of $\mathrm{TG}_{1}$ with lower limit in $\mathrm{TG}_{2}$ shows lower differentiation in these two training groups for $\alpha-\mathrm{MyHC}$ expression. The training group with overload of $7.5 \%\left(\mathrm{TG}_{3}\right)$ showed an 8.48-fold (6.59-10.91) increase.

Aiming to unambiguously differentiate $\alpha$ - and $\beta-\mathrm{MyHC}$, one ion, which is unique to $\alpha-\mathrm{MyHC}$, of $2036.48 \mathrm{~m} / \mathrm{z}$ corresponding to residues 1546-1663 (KNAQAHLKDTQL QLDDAVRA) was sequenced from spot 7. Tryptic peptides specifically from $\beta-\mathrm{MyHC}$ were not detected, suggesting that spot 7 is formed by $\alpha$-MyHC. A similar strategy to elucidate $\mathrm{MyHC}$ isoforms has been used before [11]. This result clearly showed a significant increase in $\alpha-\mathrm{MyHC}$ expression in proportion to training intensity. A clear cut among $\mathrm{TG}_{3}$ and the other two training groups was also seen in histopathological analysis and electrophoretic analyses, which showed that $\mathrm{TG}_{3}$ was clearly able to improve $\alpha-\mathrm{MyHC}$ expression (Figure 2). Since $\alpha-\mathrm{MyHC}$ up regulation in exercised-trained rat hearts is consistent with previously published data $[11,29,30]$, here we could conclude that intensity, at least in swimming training, is the key to controlling $\alpha-\mathrm{MyHC}$ expression and indeed cardiomyocite power output (Figure 1). Other studies using swimming as a training method have suggested that this practice could induce an increase in $\alpha-\mathrm{MyHC}$ expression in the rat heart [19]. The same author described little modifications in $\mathrm{MyHC}$ isoform content in trained myocardium, despite finding increase in loaded shortening velocity. These results suggest that it is possible to have significant alterations in myocardial contractile function with lower or no change in $\mathrm{MyHC}$ isoform expression, as was observed here. However, despite changes in the myosin subunit isoform expression are associated to increase in contractility by an increase in force generation, economy in ATP ratio and increased $\mathrm{Ca}^{2+}$ sensitivity, others low molecular weight sarcomeric protein, that they had not been described in this work, like myosin regulatory light chain, troponin-I, troponin- $\mathrm{T}$, alpha-tropomyosin and myosin binding protein- $\mathrm{C}$ must be considered for yours relevance for contractile mechanism [31].
Since the 1980s some important studies have reported that an increase in $\alpha-\mathrm{MyHC}$ from exercise [32-34] is able to boost cardiomyocyte power output $[4,11]$, especially for myofibrillar proteins [4]. Here, in this report, we used a combination of protein extraction under high salt quantities associated with a long and modified 2D gel run with low acrylamide concentration (8\%). These procedures allowed the visualization of high molecular mass protein maps. Otherwise, spot resolution was lower when compared to other muscle tissues' protein maps $[4,11]$. Similar data were obtained with treadmill-trained rats, in which a 1.9-fold increase of $\alpha-\mathrm{MyCH}$ expression was observed [11]. Spot 7 showed $120 \mathrm{kDa}$ of molecular weight, which is approximately half that of the predicted myosin heavy chain complete polypeptide. Furthermore, several MyHC isoforms (17) could share 93\% sequence identity [11].

Troponin, which acts as a muscular contraction regulator due to its relationship with calcium molecules, was identified in two different spots (Table 1). It is important to note that, probably, a different troponin species, which showed identical molecular mass (approximately $220 \mathrm{kDa}$ ), presented a completely different pI. While one species extracted from spot 14 showed a $\mathrm{pI}$ of 4.8 , the troponin species from spot 12 had a pI of 9.6 (Table 1). The troponin from spot 12 was only observed in protein maps from rat hearts submitted to intense exercise (TG3), suggesting that only intense exercise is capable of improving its expression at 2-DE detectable levels (data not shown).

Troponin is commonly utilized as a serum muscle injury marker in cardiac insufficiency and, consequently, pathologic hypertrophy $[27,35,36]$. For Lippi and Banfi, an increase in cTns values might be temporarily responsible for a reversible shed of cardiac blebs. Elevated levels of cTn could be due to ongoing myocardial damage or leakage of myofibrillar components and may reflect the loss of viable cardiac myocytes [37]. Myocyte injury, coronary microvascular dysfunction, and fibroblast and collagen turnover also play an important role in cardiac remodeling; extracellular matrix remodeling takes place in myocardium hypertrophy [38]. Nie et al. [39] suggest a role for exercise-induced increases in ROS in the mediation of cTn. Moreover, oxidative stress in high exercise intensity induced microvascular flow abnormalities, which in turn are associated with an increase in cTn levels observed by microscopic analyses [40]. To support this fact, the presence of an isoform of major histocompatibility complexes, that are strictly associated with immune response in nucleated cells, such as necrosis or hydrolases enzymes, was detected at higher levels in $\mathrm{TG}_{3}$. This process distinguishes between self-proteins and foreign protein antigens to elicit an effective immune response called antigen-presenting cells [41]. These data, in addition to histological analysis 
Table 2 Real time PCR results

\begin{tabular}{|c|c|c|c|c|c|c|c|c|c|c|c|c|c|c|c|c|c|c|}
\hline \multirow[t]{2}{*}{ Spot } & \multirow{2}{*}{$\begin{array}{l}\text { Obs. } \\
\text { pl }\end{array}$} & \multirow{2}{*}{$\begin{array}{l}\text { Exp. } \\
\text { pl }\end{array}$} & \multirow{2}{*}{$\begin{array}{l}\text { Obs. } \\
\text { M.M. } \\
\text { (kDa) }\end{array}$} & \multirow{2}{*}{$\begin{array}{l}\text { Exp. } \\
\text { M.M. } \\
\text { (kDa) }\end{array}$} & \multirow{2}{*}{$\begin{array}{l}\text { Sequ. } \\
\text { Match. }\end{array}$} & \multirow{2}{*}{$\begin{array}{l}\text { Sequ. } \\
\text { not } \\
\text { match. }\end{array}$} & \multirow{2}{*}{$\begin{array}{l}\text { Cover. } \\
\%\end{array}$} & \multirow{2}{*}{$\begin{array}{l}\text { e- } \\
\text { value }\end{array}$} & \multirow{2}{*}{$\begin{array}{l}\text { Swissprot } \\
\text { code }\end{array}$} & \multirow[t]{2}{*}{ Protein } & \multirow[t]{2}{*}{ Protein funtion } & \multirow{2}{*}{$\begin{array}{l}\text { CG } \\
\text { Regul. } \\
\text { factor }\end{array}$} & \multicolumn{2}{|l|}{ TG1 } & \multicolumn{2}{|l|}{ TG2 } & \multicolumn{2}{|l|}{ TG3 } \\
\hline & & & & & & & & & & & & & $\begin{array}{l}\text { Regul. } \\
\text { factor }\end{array}$ & $\begin{array}{c}\mathrm{p}- \\
\text { value }\end{array}$ & $\begin{array}{l}\text { Regul. } \\
\text { factor }\end{array}$ & $\begin{array}{c}\mathrm{p}- \\
\text { value }\end{array}$ & $\begin{array}{l}\text { Regul } \\
\text { factor }\end{array}$ & $\begin{array}{l}\mathrm{p}- \\
\text { value }\end{array}$ \\
\hline 1 & 9.0 & 9.4 & $\approx 120$ & 122 & 25 & 84 & 23.3 & 0.4 & Q8K4V5 & $\begin{array}{l}\text { High-affinity } \\
\text { immunoglobulin } \\
\text { gamma Fc } \\
\text { receptor I. }\end{array}$ & Phagocytes process & 1.00 & absent & - & absent & - & 1.01 & 0.05 \\
\hline 2 & 8.1 & 9.2 & 248 & 34.4 & 70 & 239 & 22.7 & 0.3 & Q3KRD5 & $\begin{array}{l}\text { Mitochondrial } \\
\text { import receptor } \\
\text { subunit TOM34. }\end{array}$ & $\begin{array}{l}\text { Translocase of outer } \\
\text { membrane } 34 \mathrm{kDa} \\
\text { subunit associated to } \\
\text { energy synthesis. }\end{array}$ & 1.00 & absent & - & absent & - & 1.32 & 0.05 \\
\hline 3 & 6.9 & 5.9 & 175 & 105 & 33 & 55 & 37. & 0.1 & Q60107 & $\begin{array}{l}\text { MHC class H-like } \\
\text { located } \\
\text { near the LRC, } 1 .\end{array}$ & $\begin{array}{l}\text { Immunological } \\
\text { leukocyte response. }\end{array}$ & 1.00 & absent & - & absent & - & 1.00 & 0.01 \\
\hline 4 & 4.3 & 9.7 & $\approx 250$ & 227 & 65 & 135 & 32.5 & 1.0 & AAH83554 & $\begin{array}{l}\text { Magnesium } \\
\text { transporter } \\
\text { MRS2. }\end{array}$ & $\begin{array}{l}\mathrm{Mg}^{2+} \text { mitochondria's } \\
\text { transporter }\end{array}$ & 1.00 & 1.12 & 0.05 & 1.27 & 0.05 & 1.53 & 0.01 \\
\hline 5 & 5.9 & 5.2 & $\approx 230$ & 364 & 63 & 276 & 18.6 & 0.1 & Q924V0 & $\begin{array}{l}\text { Cadherin class } 1 \\
\text { receptor. }\end{array}$ & Immune system. & 1.00 & absent & - & absent & - & absent & - \\
\hline 6 & 5.2 & 5.7 & $\approx 100$ & 314 & 72 & 213 & 25.3 & 0.6 & BAA18993 & $\begin{array}{l}\text { N-G,N-G- } \\
\text { dimethylarginine } \\
\text { dimethylamino } \\
\text { hydrolase. }\end{array}$ & $\begin{array}{l}\text { NO synthetases } \\
\text { inhibitor. }\end{array}$ & 1.00 & absent & - & 1.00 & 0.05 & 1.01 & 0.05 \\
\hline 7 & 6.4 & 9.1 & 120 & 127 & 630 & 477 & 56.9 & 0.08 & Q63356.1 & $\begin{array}{l}\text { a-Myosin heavy } \\
\text { chain. }\end{array}$ & $\begin{array}{l}\text { Primary motor of } \\
\text { muscle contraction } \\
\text { on } \\
\text { cardiac cells. }\end{array}$ & 1.00 & 1.04 & 0.05 & 0.93 & 0.01 & 1.24 & 0.05 \\
\hline 8 & 5.5 & 9.2 & 193.9 & 34.4 & 54 & 185 & 22.6 & 0.4 & Q3KRD5 & $\begin{array}{l}\text { Mitochondrial } \\
\text { import receptor } \\
\text { subunit TOM34. }\end{array}$ & $\begin{array}{l}\text { Translocase of outer } \\
\text { membrane } 34 \mathrm{kDa} \\
\text { subunit associated to } \\
\text { energy synthesis. }\end{array}$ & 1.00 & absent & - & 1.47 & 0.05 & 1.36 & 0.05 \\
\hline 9 & 6.9 & 5.2 & 192.6 & 107 & 698 & 277 & 71.6 & 0.04 & AAF37622 & $\begin{array}{l}\text { Glutamyl } \\
\text { aminopeptidase. }\end{array}$ & $\begin{array}{l}\text { Rennin-angiotensin } \\
\text { catabolism pathway. }\end{array}$ & 1.00 & 1.30 & 0.05 & 1.10 & 0.05 & 1.32 & 0.05 \\
\hline 10 & 7.3 & 9.8 & 213.0 & 82 & 48 & 270 & 15.1 & 0.09 & CAA40164 & $\begin{array}{l}\mathrm{NADH} \text { dehydrogenase, } \\
\text { mitochondrial } \\
\text { subunit 1. }\end{array}$ & $\begin{array}{l}\text { Catalyzes the first } \\
\text { dehydrogenase } \\
\text { reaction in the } \\
\text { TCA cycle }\end{array}$ & 1.00 & 1.07 & 0.05 & 1.18 & 0.05 & 1.50 & 0.05 \\
\hline 11 & 5.8 & 9.4 & 223.1 & 46 & 52 & 36 & 59.1 & 0.1 & Q60l18 & $\begin{array}{l}\text { Major } \\
\text { histocompatibility } \\
\text { complex class } 1 .\end{array}$ & $\begin{array}{l}\text { Immunological } \\
\text { leukocyte response. }\end{array}$ & 1.00 & absent & - & absent & - & 1.12 & 0.05 \\
\hline 12 & 8.3 & 9.6 & 224.9 & 215 & 76 & 135 & 36.0 & 1.0 & P23693 & $\begin{array}{l}\text { Troponin I, } \\
\text { cardiac muscle. }\end{array}$ & $\begin{array}{l}\text { Muscular contraction } \\
\text { regulator by its } \\
\text { relation with calcium } \\
\text { molecules. }\end{array}$ & 1.00 & 1.19 & 0.01 & 1.05 & 0.05 & 1.26 & 0.001 \\
\hline
\end{tabular}


Table 2 Real time PCR results (Continued)

\begin{tabular}{|c|c|c|c|c|c|c|c|c|c|c|c|c|c|c|c|c|c|c|}
\hline 13 & 5.6 & 9.2 & 240.0 & 34.4 & 58 & 185 & 23.9 & 1.0 & Q3KRD5 & $\begin{array}{l}\text { Mitochondrial } \\
\text { import receptor } \\
\text { subunit TOM34. }\end{array}$ & $\begin{array}{l}\text { Associated to energy } \\
\text { production. }\end{array}$ & 1.00 & absent & - & absent & - & 1.42 & 0.08 \\
\hline 14 & 4.8 & 9.6 & 232.2 & 21 & 44 & 167 & 20.9 & 2.2 & P23693 & $\begin{array}{l}\text { Troponin I, } \\
\text { cardiac muscle. }\end{array}$ & $\begin{array}{l}\text { Muscular contraction } \\
\text { regulator by its } \\
\text { relation } \\
\text { with calcium } \\
\text { molecules. }\end{array}$ & 1.00 & 1.00 & 0.05 & 1.00 & 0.05 & 1.1 & 0.05 \\
\hline 15 & 5.5 & 6.1 & 249.9 & 42 & 26 & 62 & 29.5 & 1.0 & Q861Q1 & $\begin{array}{l}\text { Major } \\
\text { histocompatibility } \\
\text { complex } \\
\text { class } 1\end{array}$ & $\begin{array}{l}\text { Involved in the } \\
\text { immunological } \\
\text { leukocyte response. }\end{array}$ & 1.00 & 1.00 & 0.05 & 1.02 & 0.05 & 1.31 & 0.05 \\
\hline 16 & 8.6 & 9.2 & 261 & 34.4 & 73 & 236 & 23.6 & 0.8 & Q3KRD5 & $\begin{array}{l}\text { Mitochondrial } \\
\text { import receptor } \\
\text { subunit TOM34. }\end{array}$ & Energy synthesis & 1.00 & absent & - & absent & - & 1.0 & 0.05 \\
\hline 17 & 4.7 & 5.2 & 225 & 107 & 66 & 909 & 6.8 & 0.04 & AAF37622 & $\begin{array}{l}\text { Glutamyl } \\
\text { aminopeptidase. }\end{array}$ & $\begin{array}{l}\text { Rennin-angiotensin } \\
\text { catabolism pathway }\end{array}$ & 1.00 & absent & - & 1.03 & 0.05 & 1.13 & 0.05 \\
\hline
\end{tabular}

Differential proteins identified by MALDI ToF peptide mass fingerprinting of multiple proteins from rat left ventricles. As a standard, false Discovery rate was calculated as lower than $15 \%$. 


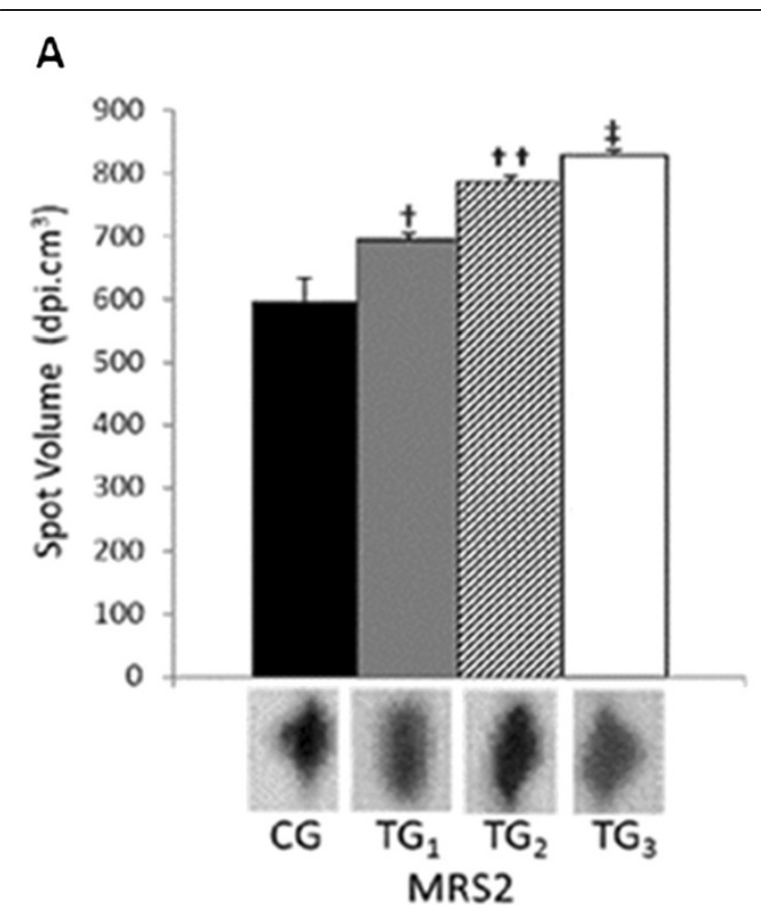

B

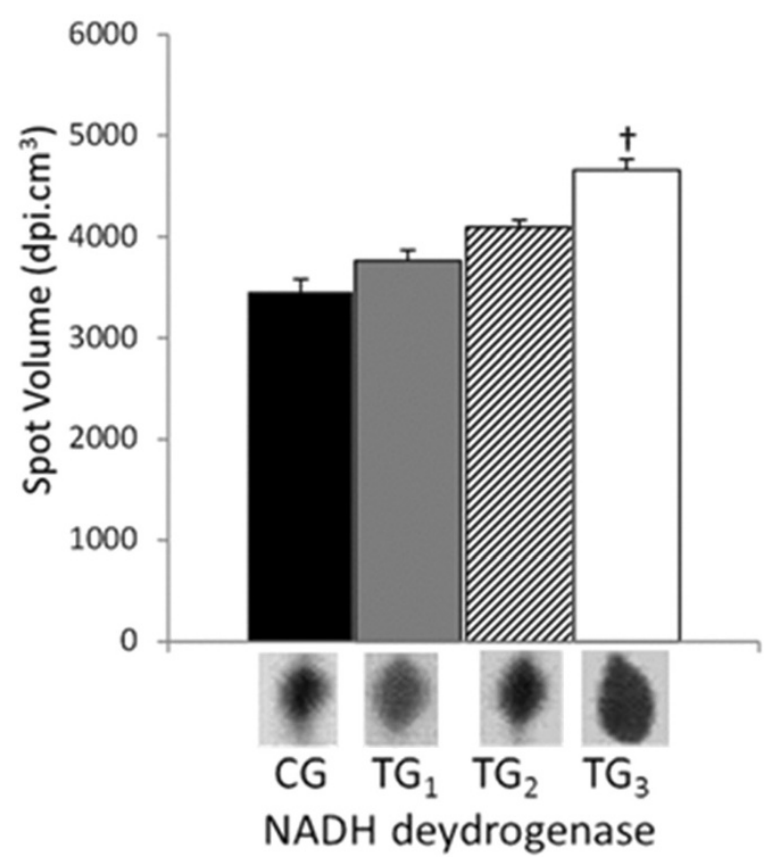

Figure 2 MRS2 and NADH protein quantity analyses. MRS2 (A) and NADH dehydrogenase (B) expression evaluated by high molecular mass 2-DE technique in rats left ventricle cardiomiocities. CG corresponds to control group; $\mathrm{TG}_{1} ; \mathrm{TG}_{2}$ and $\mathrm{TG}_{3}$ correspond respectively to $2.5 ; 5.0$ and 7.5 to training groups. Different spots volumes are determinate by using software Bionumerics ${ }^{\mathrm{TM}}$. Simbols $\boldsymbol{\dagger}, \boldsymbol{\dagger}+$ and $\ddagger$, represent the statistical difference between respectively groups. Statistical analyses were conducted by ANOVA $(P<0.05)$. All studies were performed in triplicate. previously described, which show a large necrosis area as well as leucocytes presence, suggested cardiac muscle injury caused by intense exercise $\left(\mathrm{TG}_{3}\right)$, leading us to believe that $7.5 \%$ overload exercise for 8 weeks brings real benefits to the animal but also causes clear injuries and further decreases in animal health.

\section{Exercise-induced changes in the expression of gene products involved in energy metabolism}

An important signal for exercise adaptation consists of greater expression of proteins associated with the oxidative metabolism, such as oxidoreductases, mitochondrial membrane transporters [42]. The mitochondrial internal membrane exerts a fundamental role in oxidative phosphorylation and also in electron transport. Moreover, the translocases move through the mitochondrial membrane and have a logical consequence for an important physiological process known as ATP synthesis [43,44]. In eukaryotic cells, the final stage of nutrients oxidation occurs in mitochondria, with fast oxidation of $\mathrm{NADH}$ and $\mathrm{FADH}_{2}$ produced in glycolysis, tricarboxilic cycle, ß-oxidation of fatty acids and amino acid oxidation.

In this study we found the presence of a NADHdehydrogenase in all training groups and in the control (Table 1; Figure 2), which developed a key role in electron transfer in the respiratory chain to $\mathrm{Q}$ coenzyme [45]. The expression of that isoform of NADH dehydrogenase was clearly improved from control groups to more intensely trained rats (Figure 2), leading to 1.30 fold at $\mathrm{TG}_{3}$. It's important to cite that NADH dehydrogenase here analyses, maybe an isoform and that this up regulation could not be related to all protein class here evaluated. Additionally, it was only in rat hearts from $\mathrm{TG}_{3}$ group that the synthesis of membranes translocases was observed at detectable levels by the techniques applied here. These translocases are commonly associated with ATP's and $\mathrm{H}^{+}$transport to cytosol (Table 1).

Howlett and Willis (cited by [46]) observed that the isocitrate dehydrogenase (IDH) activity is higher in mitochondria from striated muscle, suggesting that it may rely on this enzyme as a regulatory site. This enzyme catalyzes the first dehydrogenase reaction in the TCA cycle and produces $\mathrm{NADH}+\mathrm{H}^{+}$, which is the substrate of NADH dehydrogenase. This may explain an over expression of NADH dehydrogenase, as observed in $\mathrm{TG}_{3}$ in the present study (Figure 2). Although mitochondria exert the essential role of ATP production, they are also the primary source of cellular reactive oxygen species $[47,48]$. In a recent review Powers and Jackson [49] suggested that common metabolic changes and ROS generation may predominantly occur by contracting skeletal and heart muscle during different exercise protocols. An exception to this rule is an experiment whereby muscle damage occurs, and in this situation, 
inflammatory processes may play an important role in radical production. It is well accepted that exercise provides intrinsic protection to the heart [50]. Recent reports have associated ROS production with apoptosis after physical effort, a situation in which the apoptotic mitochondrial pathways may play a major role by releasing cytochrome $\mathrm{c}$ and activating initiators such as caspases [46]. An increase in mitochondrial oxidant production is generally accepted as a cause of myocardial cell loss via apoptosis and necrosis [50]. These data corroborates with myocite modifications observed in $\mathrm{TG}_{3}$ by microscopy (Additional file 1: Figure S1), explaining the reduction in exercise benefits during the exercise training stage.

During exercise, $\mathrm{H}^{+}$concentration is enhanced, being this process is commonly associated with force generation decline in muscles, also causing a reduction in cross bridge activation by competitively inhibiting $\mathrm{Ca}^{2+}$ binding to troponin $\mathrm{C}$. Moreover, proton concentration reduces $\mathrm{Ca}^{2+}$ - ATPase re-uptake in sarcoplasm and inhibits myofibrillar ATPase [40]. Mitochondrial ROS generation can lead to a calcium overload, consequently decreased ATP production, and may cause the mitochondrial permeability transition pore (PTP) to open, further decreasing ATP production and releasing cytochrome c. However, the increase of translocases can increase the transport of $\mathrm{H}^{+}$reducing the competition with calcium during the exercise, which would make the most of the positive effect of the exercise.

Finally, another important gene product here detected and probably involved in the increase of ATP synthesis consists in an isoform of magnesium homeostasis factor. homolog, MRS2, 1.5 fold (Figure 2, Table 1), a major $\mathrm{Mg}^{2+}$ mitochondria's transporter being their function extremely important for respiratory complex I and cell viability maintenance [51]. This protein family is characterized for a conserved GMN C-terminus (Gly-Met-Asn) in the transmembrane domains. Furthermore, this is the region responsible for $\mathrm{Mg}^{2+}$ selective filter [52] This divalent ion is abundant inside the cell and plays a fundamental role in many biochemical and regulatory functions being his concentration maintained by an transmembrane electrochemical potential [51]. In cardiac muscle $\mathrm{Mg}^{2+}$ may be involved in the ATPase phosphate-release step causing inhibition of myofibril sarcoplasmic reticulum $\mathrm{Ca}^{2+}$-transporting ATPases under anoxia. This last condition could be improved by high intensity contraction in maximal exercise, when the ATP-PCr system can occur to maintain a relatively constant energy supply [53]. This finding in the present study is in accordance with the increase of aerobic capacity by mitochondrial biogenesis and/or workload improvement as a consequence of swimming training but, one more time, it's important to cite that maybe an isoform and that this up- or down regulation could not be related to all protein class here evaluated.

\section{Conclusions}

In summary, our study evidenced left ventricular hypertrophy and these data seems to be correlated at molecular levels with proteins of high molecular masses. This increase suggests a clear correlation with the level of intensity which the individuals underwent. It demonstrates that interval training with high intensity compared with low and moderate intensity training led to a remarkable increase in $\alpha-\mathrm{MyHC}$ and troponin expressions in the left ventricle of cardiac myocyte of $R$. norvegicus. Another important data is the significant degree of cellular injury in left ventricle in individual submitted to high intensity, when compared with the individuals submitted to low and moderate intensities. Thus, we conclude that $7.5 \%$ overload exercise for 8 weeks may possibly improve contractile function for the animal, but may also cause injuries and consequently, reduce the animal's health. These modifications seem to be related to modifications in contractile and metabolic proteins, previously elucidated by proteomics and molecular analyses. Data here reported add more knowledge to molecular exercise studies.

\section{Methods}

\section{Animal group design}

All procedures are in accordance with the ethics guidelines for research at the University of Brasília and were approved by the ethics committee (UnbDOC n.48695/ 2010). Twenty isogenic male Wistar adult rats (Rattus novergicus), with age varying from 80-90 days, were equally randomized into four groups, one being the sedentary negative control group (CG) and three the swimmingtrained groups (TG's). The control group was maintained in isolated cages receiving water and food ad libitum.

\section{Exercise training protocol}

The animals were adapted to the water environment for three weeks, in the same place as the training sessions, in a cylindrical training tank with a smooth surface, measuring $60 \mathrm{~cm}$ in diameter by $120 \mathrm{~cm}$ in depth, kept at a constant temperature $\left(32 \pm 0.5^{\circ} \mathrm{C}\right)$. The training period was corporate to 5 consecutive days of $30 \mathrm{~min}$ of swimming sessions for 8 weeks. Training groups were characterized by the overloaded applied, respectively $2.5 \%\left(\mathrm{TG}_{1}\right), 5.0 \%\left(\mathrm{TG}_{2}\right)$ and $7.5 \%\left(\mathrm{TG}_{3}\right)$ (Figure 3$)$. The overload was determined weekly by individual animal body weight and attached to the animal's chest. Aiming to minimize the animal's stress without promoting physiological adaptations derived from physical exercise, training group animals were submitted to the water environment before the swimming exercise protocol started. At the end of training period, all animals 


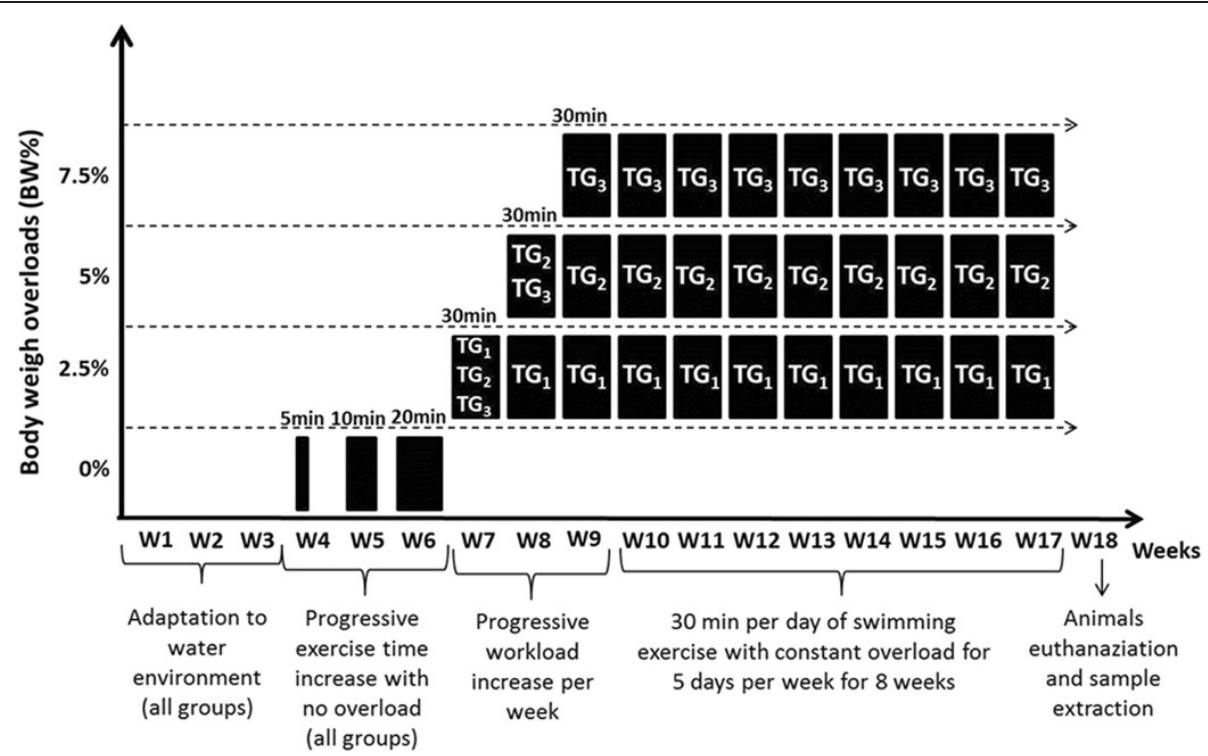

Figure 3 Exercise training period. Overview from the exercise experiment design indicating the progress of time and overload trough 8 weeks of swimming exercise.

immediately underwent euthanasia after the last training session by decapitation after being anaesthetized with $90 \mathrm{mg} \cdot \mathrm{Kg}^{-1}$ of ketamin and $10 \mathrm{mg} \cdot \mathrm{Kg}^{-1}$ of xilasin provided by muscle injection.

\section{Measuring the animals' training adaptation}

In order to verify the animals' training status, lactate was evaluated and used as parameter for rat adaptation to aerobic performance. At the beginning, (in the first week) and at the end (in the last week) of the training process, maximal lactate steady state (MLSS) was measured by an incremental load swimming test with overload increased by $1 \%$ of body weight each $3 \mathrm{~min}$, with $90 \mathrm{~s}$ of interval until weariness [54]. Moreover, $25 \mu \mathrm{L}$ of blood samples were collected from a tail tip cut during the exercise tests and deposited in tubes containing $50 \mu \mathrm{L}$ of $1 \%$ sodium fluoride. MLSS was measured in a lactometer model YSI $2700 \mathrm{~S}^{\mathrm{TM}}$ (Yellow Springs Inc. USA). The variable maximum lactate used for MLSS identification was $0.07 \mathrm{mM} \cdot \mathrm{min}^{-1}$.

\section{Heart preparation}

Complete heart of each animal was removed and placed in an RNAse free sterile apparatus. The left ventricle was separated in three parts. Two were frozen in liquid nitrogen and stored at $-80^{\circ} \mathrm{C}$ until protein and RNA extractions. The third section was stored in $10 \%$ formol for $48 \mathrm{~h}$.

\section{Histological sample preparation}

After formol (10\%) fixation, samples were paraffin embedded and sliced in 3 to $4 \mu \mathrm{M}$ thickness. After the histological sectioning, tissues were stained with hematoxylin and eosin and further analyzed in an Eclipse E200 POL ${ }^{\mathrm{TM}}$ optical microscope (Melville, NY).

\section{Protein extraction}

Muscle proteins were extracted from rat heart left ventricles. An amount of $150 \mathrm{mg}$ from each sample was homogenized in $10 \mathrm{mM}$ Tris-EDTA buffer pH 7.4 containing $25 \mathrm{mM}$ sucrose, $2 \mathrm{mM}$ EDTA, and further centrifuged at $1,000 \mathrm{~g}$ at 22 to $25^{\circ} \mathrm{C}$, as previously described by Short et al. [55]. The pellet, containing the myofibrillar fraction, was re-homogenized in $10 \mathrm{mM}$ Tris- $\mathrm{HCl}$ buffer $\mathrm{pH} 7.2$ containing $176 \mathrm{mM} \mathrm{KCl}$ and $2 \mathrm{mM}$ EDTA. Bradford's method [56], was used for protein quantification. After that, an aliquot was adjusted to a concentration of $3 \mathrm{mg} \cdot \mathrm{ml}^{-1}$ and then dissolved fourfold in sample loading buffer $(66 \mathrm{mM}$ Tris- $\mathrm{HCl} \mathrm{pH} 6.7$ containing $19 \mathrm{mM}$ EDTA, $1.0 \% \mathrm{v} / \mathrm{v}$ SDS, $0.008 \% \mathrm{v} / \mathrm{v}$ bromophenol blue, $810 \mathrm{mM} \beta$-mercaptoethanol and $40 \% \mathrm{v} / \mathrm{v}$ glycerol).

\section{Electrophoretical analyses}

SDS-PAGE 12\% was performed according to Laemmli [57]. The muscle sample was then loaded on $0.75 \mathrm{~mm}$ thick polyacrylamide gels for protein separation. The discontinuous gel recipe was used, consisting of an $8 \%$ separation gel, a $4 \%$ stacker gel, and $30 \%$ glycerol in the gel matrix. Samples were run in triplicate with CG and TG's samples in adjacent lanes. Gels were run for $20 \mathrm{~h}$ at $275 \mathrm{~V}$. Gels were fixed overnight in $50 \% \mathrm{vol} / \mathrm{vol}$ methanol and $10 \% \mathrm{vol} / \mathrm{vol}$ acetic acid. Gels were silver stained using a protocol suggesting by Blum et al. [58] and repeated in triplicate. 
Isoelectric focusing and molecular mass separation for 2-DE were conducted according to Gorg et al. [59], with minor modifications obtained from Short et al. [55] using $13 \mathrm{~cm}$ immobilized pH gradient (IPG) strips with a 3-11 pH range and a Multiphor II $^{\mathrm{TM}}$ electrophoresis system (GE HealthCare). A total of $500 \mu \mathrm{g}$ of each extract was precipitated using a $2 \mathrm{D}$ Clean-Up Kit (GE HealthCare $^{\mathrm{TM}}$ ) and re-suspended in $250 \mu \mathrm{l}$ solution of 2\% CHAPS, $8 \mathrm{M}$ urea, $7 \mathrm{mg} \cdot \mathrm{ml}^{-1}$ dithiothreitol (DTT) and $2 \%$ IPG Buffer. Strips were hydrated in this solution for 16 hours. Isoelectric focusing was carried out in a gradient mode for $30 \mathrm{~min}$ at $500 \mathrm{~V}, 90 \mathrm{~min}$ at $1000 \mathrm{~V}$, $90 \mathrm{~min}$ at $3500 \mathrm{~V}$ and 6 hours at $3500 \mathrm{~V}$ at $2 \mathrm{~mA}$ and $5 \mathrm{~W}$. After the first dimension, strips were equilibrated in a solution of $6 \mathrm{M}$ urea, 1\% DTT and 2\% SDS for $15 \mathrm{~min}$ and then applied to gels. A second dimension for high molecular mass proteins was performed in $18 \times 16 \times 0.2 \mathrm{~cm}$ SDS-PAGE $8 \%$ gels [55]. Electrophoresis was conducted in a Hoefer system (GE HealthCare ${ }^{\mathrm{TM}}$ ) at $250 \mathrm{~V}, 40 \mathrm{~mA}$ and $10 \mathrm{~W}$ for $8 \mathrm{~h}$. The broad range of isoelectric point marker (GE HealthCare ${ }^{\mathrm{TM}}$ ) was also used for subsequent pI identification on gels.

\section{In silico gel analysis}

All gels were screened on an HP scanner, model Scanjet 8290 and afterwards analyzed by BioNumerics ${ }^{\mathrm{TM}}$ v. 4.5 (Applied Maths ${ }^{\mathrm{TM}}$ ) software. To analyze all the gel images, they were all converted to TIFF files. A calibration curve was applied to convert all colors into gray tones (16-bit, $600 \mathrm{dpi}$ ) and convert them into pixel values. All technical replicates were aligned and screened by the software in order to identify the same vectors. Every artifacts and unreliable spots were eliminated by manual inspection. An unreliable spot was defined as not appearing on each of the gel images of the same sample. The spots were located and analyzed by their molecular mass and isoelectric point, concentration and matched by their similarity and spot area and densitometry (volume: pixels per inch) were also counted. In order to define the spot's differential expression a linear regression was performed by the software and a correlation cut off was applied and gels with $\mathrm{R}^{2}$ lower than 0.8 were discarded. Mean value of spot volume (dpi) from all three replicate were using to describe the spot density and for further comparison of protein expression, taking into account spots with relative volume equal to or bigger than $0.1 \mathrm{dpi}$. The spots had to present at least a one fold change were select to comparison with the CG 2D gel with the higher $\mathrm{R}^{2}$. Student's $t$-test was applied and differences of $p<0.05$ were considered significant.

\section{Protein identification by MALDI-TOF}

All spots defined by technical reproducibility described above and increase or decrease at least one fold when compared to the same spots in control group $(\mathrm{p} \leq 0,005)$ were excised from gels using a scalpel and each one placed in a $1.5 \mu \mathrm{l}$ micro tube. Protein in-gel digestion was carried out with Gold sequencing grade trypsin (Promega $^{\mathrm{TM}}$ ) according to Shevchenko et al. [60]. $300 \mu \mathrm{l}$ of $100 \%$ acetonitrile was added to tubes for $5 \mathrm{~min}$. Supernatant was removed and spots were dried in a SpeedVac for $5 \mathrm{~min}$. Samples were incubated for $60 \mathrm{~min}$ at $56^{\circ} \mathrm{C}$ in a solution containing $50 \mu \mathrm{l}$ of $10 \mathrm{mM}$ DTT and $100 \mathrm{mM} \mathrm{NH}_{4} \mathrm{HCO}_{3}$. The solution was replaced with $50 \mu \mathrm{l}$ of $55 \mathrm{mM}$ iodoacetamide and $100 \mathrm{mM} \mathrm{NH} \mathrm{NCO}_{3}$ and incubated in darkness for $45 \mathrm{~min}$. Spots were rinsed twice with MilliQ ${ }^{\mathrm{TM}}$ water (Millipore ${ }^{\mathrm{TM}}$ ) for $10 \mathrm{~min}$, and exposed to $100 \mu \mathrm{l}$ of $100 \%$ acetonitrile for $5 \mathrm{~min}$. Excess acetonitrile was removed and again spots were dried in a SpeedVac for $5 \mathrm{~min}$. Protein digestion was carried out using $650 \mathrm{ng}$ trypsin diluted in $50 \mu \mathrm{l}$ of $50 \mathrm{mM}$ $\mathrm{NH}_{4} \mathrm{HCO}_{3}$ and $6 \mathrm{mM} \mathrm{CaCl}$, with overnight incubation at $37^{\circ} \mathrm{C}$. The peptides derived from tryptic digestion were analyzed as described by Henzel et al. [61] using an UltraFlex II ${ }^{\mathrm{TM}}$ MALDI-TOF (Matrix-Assisted Laser Desorption Ionization Time-of-Flight, Bruker Daltonics ${ }^{\mathrm{TM}}$, Billerica, MA). A sample of $2 \mu \mathrm{l}$ was mixed in $6 \mu \mathrm{l}$ of $0.1 \% \alpha$-cyano-4-hydroxycinnamic acid, $0.1 \%$ trifluoroacetic acid dissolved in acetonitrile (1:1). A volume of $0.5 \mu \mathrm{l}$ was applied to a MALDI plate and dried at room temperature. Spectrometry was operated in a linear mode for MS acquisition and reflected mode for MS/MS acquisitions using modulated power with 200 random shoots. Data were saved in standard Bruker software format. Spots were identified using Peptide Mass Fingerprinting (PMF). Peptide mass lists were produced automated analysis tools of mass spectrometer previously described [62]. Data were smoothed (Gaussian, 2 chan peak width), baseline subtracted (100 chan peak width) and an adaptive ( $\times$ 8.0) threshold applied as described by Holloway et al. [63]. Monoisotopic peak (25\% centroid) selection was restricted to 15 peptides over $600-40000 \mathrm{~m} / \mathrm{z}$, and the peak list searched against the Swiss-Prot database restricted to Rattus novergicus databank using a locally implemented MASCOT (www. matrixscience.com) server. The enzyme specificity was trypsin, allowing one missed cleavage, carbamidomethyl modification of cysteine (fixed), oxidation of methionine (variable). Protein identification was accepted based on a significant Mowse score

\section{Quantification of MyHC mRNA by real time qPCR}

Total RNA was extracted with the Trizol ${ }^{\mathrm{TM}}$ reagent (Invitrogen ${ }^{\mathrm{TM}}$, USA) from $25 \mathrm{mg}$ of each animal's ventricle using standard protocol. Total RNA from individual animals from different training groups was pooled together. This provided RNA samples from the untrained group and from the other groups: $2.5 \%\left(\mathrm{TG}_{1}\right), 5.0 \%\left(\mathrm{TG}_{2}\right)$ and 
7.5\% $\left(\mathrm{TG}_{3}\right)$. The cDNA was generated using a High Capacity cDNA Archive Kit (Applied Biosystems ${ }^{\mathrm{TM}}$ ) following the manufacturer's instructions. A TaqMan Gene expression assay for myosin, heavy polypeptide 6 , cardiac muscle, alpha (Myh6, Rn00568304_m1) was bought from Applied Biosystems ${ }^{\mathrm{TM}}$ (Foster City, CA). Equal amounts of RNA $(0.5 \mu \mathrm{g})$ were reverse transcribed using High $\mathrm{Ca}$ pacity cDNA Archive (Applied Biosystems ${ }^{\mathrm{TM}}$ ) and submitted to qPCR. TaqMan assays were carried out with a StepOnePlus instrument (Applied Biosystems ${ }^{\mathrm{TM}}$, Foster City, CA) in $20 \mu \mathrm{l}$ reactions containing $0.5 \mu \mathrm{l}$ of TaqMan Gene expression Assays $(20 \times), 12,5 \mu \mathrm{l}$ of TaqMan Universal PCR Master Mix $(2 \times)$ and $2 \mu \mathrm{l}$ of template cDNA $(100 \mathrm{ng})$. After initial denaturation at $95^{\circ} \mathrm{C}$ for $10 \mathrm{~min}$, amplifications were carried out in 40 cycles at $95^{\circ} \mathrm{C} / 15 \mathrm{~s}$ and $60^{\circ} \mathrm{C} / 1 \mathrm{~min}$. Comparative CT (crossing threshold) method was used to establish differential expression among training groups and control. The constitutive rRNA18S gene expression was used for data normalization. Relative quantitation was carried out using $\Delta \Delta C_{\mathrm{T}}$ method based on three technical replicates.

\section{Additional files}

Additional file 1: Figure S1. Cross-sections of left ventricle. Crosssections of left ventricle from rats heart stained with haematoxylin and eosin for hystopathological analysis. A) Cardiac fibers from left rats ventricles pertaining to CG with a normal size and shape. B) TG1 with a normal aspect indicating no clear pathological alteration. C) TG2 shows a small sclerotic area (I) with infiltration of granule lipofuscin (I). D) TG3 shows areas with increased fibrosis (II) and an extended area with necrosis (III). N marks the nucleus in groups A, B and C. The image was magnified by 400 times and photographed with a camera Sony ${ }^{\mathrm{TM}}$ model DSC-H1 (MyHC).

Additional file 2: Figure S2. SDS-PAGE MyHC isoforms. SDS-PAGE silver stained control group (CG). TG1; TG2 and TG3 correspond respectively to $2.5 ; 5.0$ and 7.5 to overload training groups. The arrow indicates the myosin heavy chain.

Additional file 3: Figure S3. Two-dimensional electrophoretic evaluation of left ventricle high molecular mass proteins. Representative silver stained high-molecular mass two-dimensional gel (A) and further spot density analyses (B). The arrows indicate the selected spots further identified by MS analysis.

\section{Abbreviations}

a-MyHC: a -myosin heavy chain; $\beta$ - MyHC: $\beta$-myosin heavy chain; 2-DE: twodimensional electrophoresis; ATP: adenosine triphosphate; CDNA: complementary deoxyribonucleic acid; CG: control groups; CHAPS: 3-[(3-cholamidopropyl)dimethylammonio]-1-propanesulfonate; cTn: cardiac troponin; DTT: dithiothreitol; EDTA: ethylenediaminetetraacetic acid; $\mathrm{FADH}_{2}$ : flavin adenine dinucleotide, hydroquinone form; IEF: isoelectric focusing; IPG: immobilized pH gradient; MALDI-ToF: matrix-assisted laser desorption ionization time-of-flight; MLC: myosin light chain; MLSS: maximal lactate steady state; Mn-SOD: manganese-superoxide dismutase; mRNA: messenger ribonucleic acid; MS: mass spectrometry; MS/MS: tandem mass spectrometry; MyHC: myosin heavy chain; NADH: nicotinamide adenine dinucleotide at reduced form; NCBI: National Center for Biotechnology Information; PMF: peptide mass fingerprinting; QPCR: real-time polymerase chain reaction; $R^{2}$ : coefficient of linear regression determination; RNA: ribonucleic acid; SDS-PAGE: sodium dodecyl sulphate polyacrilamide gel electrophoresis; TCA cycle: tricarboxylic acid cycle; $\mathrm{TG}_{1}: \mathrm{TG}_{2}$ and $\mathrm{TG}_{3}$, training groups with overload of 2.5\%, $5.0 \%$ and $7.5 \%$ respectively; Tris-
EDTA: hydroxymethyl aminomethane-ethylenediaminetetraacetic acid; TrisHCl: ethylenediaminetetraacetic acid - Hydrochloric acid.

\section{Competing interests}

Authors declare there are absolute not political, personal, religious, ideological, academic, intellectual, commercial conflict of interests in this work.

\section{Authors' contributions}

LAOR it conceived and participates of design of the study, exercise training, electrophoretical and in silico gel analysis and drafted the manuscript. BP participates of exercise training and electrophoretical analyses. DHB does the Histological sample preparation and analyses. RVO helped to draft the manuscript. RV participates of molecular studies (real time GPCR). GD carried out the protein identification by MALDI-TOF. RWP participates of molecular studies (real time qPCR) and helped to draft the manuscript. OLF participates conception and design and coordination of the study and helped to draft the manuscript. All authors read and approved the final manuscript.

\section{Acknowledgments}

This work was supported by CNPq, CAPES, FAPDF and UCB.

\section{Author details}

'Centro de Análises Proteômicas e Bioquímicas, Programa de Pós-Graduação em Ciências Genômicas e Biotecnologia, Universidade Católica de Brasília, Brasília-DF, Brazil. ${ }^{2}$ Programa de Pós-Graduação em Educação Física, da Universidade de Brasília. ${ }^{3}$ Departamento de Biologia, Universidade Federal de Juiz de Fora, Juiz de Fora-MG, Brazil. ${ }^{4}$ Universidade Federal do Rio de Janeiro, Protemics Unit, Rio de Janeiro, Brazil. ${ }^{5}$ Pos-graduação em patologia molecular, Universidade de Brasilia, Brasilia, DF, Brazil.

Received: 27 December 2011 Accepted: 28 August 2012

Published: 5 September 2012

\section{References}

1. lemitsu M, et al: Physiological and pathological cardiac hypertrophy induce different molecular phenotypes in the rat. Am J Physiol Regul Integr Comp Physiol 2001, 281(6):R2029-R2036.

2. Vivanco F, et al: Proteomics and cardiovascular disease. Rev Esp Cardiol 2003, 56(3):289-302.

3. Bernardo BC, Weeks KL, Pretorius L, McMullen JR: Molecular distinction between physiological and pathological cardiac hypertrophy: experimental findings and therapeutic strategies. Pharmacol Ther 2010, 128(1):191-227.

4. Burniston JG: Changes in the rat skeletal muscle proteome induced by moderate-intensity endurance exercise. Biochim Biophys Acta 2008, 1784 (7-8):1077-1086.

5. Bishop JE, Lindahl G: Regulation of cardiovascular collagen synthesis by mechanical load. Cardiovasc Res 1999, 42(1):27-44.

6. Gonzalez A, Lopez B, Diezl J: Myocardial fibrosis in arterial hypertension. Eur Heart J Suppl 2002, 4(suppl_D):D18-D22.

7. Verzola RM, et al: Early remodeling of rat cardiac muscle induced by swimming training. Braz J Med Biol Res 2006, 39(5):621-627.

8. Anand IS, Florea VG, Fisher L: Surrogate end points in heart failure. $J \mathrm{Am}$ Coll Cardiol 2002, 39(9):1414-1421.

9. Demirel HA, et al: Exercise-induced alterations in skeletal muscle myosin heavy chain phenotype: dose-response relationship. J Appl Physiol 1999, 86(3):1002-1008

10. Joumaa WH, Leoty C: A comparative analysis of the effects of exercise training on contractile responses in fast- and slow-twitch rat skeletal muscles. J Comp Physiol B 2002, 172(4):329-338.

11. Burniston JG: Adaptation of the rat cardiac proteome in response to intensity-controlled endurance exercise. Proteomics 2009, 9(1):106-115.

12. Diffee GM, Chung E: Altered single cell force-velocity and power properties in exercise-trained rat myocardium. J Appl Physiol 2003, 94(5):1941-1948.

13. Scheinowitz $M$, et al: Short- and long-term swimming exercise training increases myocardial insulin-like growth factor-I gene expression. Growth Horm IGF Res 2003, 13(1):19-25. 
14. Hashimoto T, et al: Expression of MHC-beta and MCT1 in cardiac muscle after exercise training in myocardial-infarcted rats. J Appl Physiol 2004 97(3):843-851

15. Herron TJ, Korte FS, McDonald KS: Loaded shortening and power output in cardiac myocytes are dependent on myosin heavy chain isoform expression. Am J Physiol Heart Circ Physiol 2001, 281(3):H1217-H1222.

16. Hinken AC, Korte FS, McDonald KS: Porcine cardiac myocyte power output is increased after chronic exercise training. J Appl Physio/ 2006, 101(1):40-46.

17. Guelfi KJ, et al: A proteomic analysis of the acute effects of high-intensity exercise on skeletal muscle proteins in fasted rats. Clin Exp Pharmacol Physiol 2006, 33(10):952-957.

18. Gelfi C, et al: The human muscle proteome in aging. J Proteome Res 2006, 5(6):1344-1353.

19. Diffee GM: Adaptation of cardiac myocyte contractile properties to exercise training. Exerc Sport Sci Rev 2004, 32(3):112-119.

20. Diffee $\mathrm{GM}$, et al: Microarray expression analysis of effects of exercise training: increase in atrial MLC-1 in rat ventricles. Am J Physiol Heart Circ Physiol 2003, 284(3):H830-H837.

21. Lindsey $\mathrm{ML}$, et al: $\mathrm{A}$ multidimensional proteomic approach to identify hypertrophy-associated proteins. Proteomics 2006, 6(7):2225-2235.

22. White MY, et al: Proteomics of ischemia/reperfusion injury in rabbit myocardium reveals alterations to proteins of essential functional systems. Proteomics 2005, 5(5):1395-1410.

23. Korte FS, et al: Power output is linearly related to $\mathrm{MyHC}$ content in rat skinned myocytes and isolated working hearts. Am J Physiol Heart Circ Physiol 2005, 289(2):H801-H812.

24. Herron TJ, McDonald KS: Small amounts of alpha-myosin heavy chain isoform expression significantly increase power output of rat cardiac myocyte fragments. Circ Res 2002, 90(11):1150-1152.

25. Harjola VP, Kiilavuori K, Virkamaki A: The effect of moderate exercise training on skeletal muscle myosin heavy chain distribution in chronic heart failure. Int J Cardiol 2006, 109(3):335-338.

26. Molloy MP, et al: Overcoming technical variation and biological variation in quantitative proteomics. Proteomics 2003, 3(10):1912-1919.

27. Adams JE 3rd, et al: Cardiac troponin I. A marker with high specificity for cardiac injury. Circulation 1993, 88(1):101-106

28. Westbrook JA, et al: The human heart proteome: Two-dimensional maps using narrow-range immobilised pH gradients. Electrophoresis 2006, 27(8):1547-1555

29. Rafalski K, Abdourahman A, Edwards JG: Early adaptations to training: upregulation of alpha-myosin heavy chain gene expression. Med $\mathrm{SC}$ Sports Exerc 2007, 39(1):75-82.

30. Jin $\mathrm{H}$, et al: Effects of exercise training on cardiac function, gene expression, and apoptosis in rats. Am J Physiol Heart Circ Physiol 2000, 279(6):H2994-H3002

31. Schaub MC, et al: Modulation of contractility in human cardiac hypertrophy by myosin essential light chain isoforms. Cardiovasc Res 1998, 37(2):381-404

32. Malhotra A, et al: Correlation of myosin isoenzyme alterations with myocardial function in physiologic and pathologic hypertrophy. Eur Heart J 1984, 5(Suppl F):61-67.

33. Rupp H: Differential effect of physical exercise routines on ventricular myosin and peripheral catecholamine stores in normotensive and spontaneously hypertensive rats. Circ Res 1989, 65(2):370-377.

34. Rappaport $L$, et al: Isomyosins, microtubules and desmin during the onset of cardiac hypertrophy in the rat. Eur Heart J 1984, 5(Suppl F):243-250.

35. Agianian B, et al: A troponin switch that regulates muscle contraction by stretch instead of calcium. EMBO J 2004, 23(4):772-779.

36. Liu X, Pollack GH: Stepwise sliding of single actin and Myosin filaments. Biophys J 2004, 86(1 Pt 1):353-358.

37. Lippi G, Banfi G: Exercise-related increase of cardiac troponin release in sports: An apparent paradox finally elucidated? Clin Chim Acta 2010, 411(7-8):610-611.

38. Moreno $V$, et al: Serum levels of high-sensitivity troponin T: a novel marker for cardiac remodeling in hypertrophic cardiomyopathy. J Card Fail 2010, 16(12):950-956.

39. Nie J, Close G, George KP, Tong TK, Shi Q: emporal association of elevations in serum cardiac troponin $\mathrm{T}$ and myocardial oxidative stress after prolonged exercise in rats. Eur J Appl Physiol 2010, 110(6):1299-303.
40. Goette A, et al: Acute atrial tachyarrhythmia induces angiotensin II type 1 receptor-mediated oxidative stress and microvascular flow abnormalities in the ventricles. Eur Heart J 2009, 30(11):1411-20.

41. Smith SC, Allen PM: Expression of myosin-class II major histocompatibility complexes in the normal myocardium occurs before induction of autoimmune myocarditis. Proc Natl Acad Sci USA 1992, 89(19):9131-5.

42. Bye $A$, et al: Aerobic capacity-dependent differences in cardiac gene expression. Physiol Genomics 2008, 33(1):100-9.

43. Ravi Kiran T, Subramanyam MV, Asha Devi S: Swim exercise training and adaptations in the antioxidant defense system of myocardium of old rats: relationship to swim intensity and duration. Comp Biochem Physiol $B$ Biochem Mol Biol 2004, 137(2):187-96.

44. Vander Heiden $M G$, et al: Outer mitochondrial membrane permeability can regulate coupled respiration and cell survival. Proc Natl Acad Sci USA 2000, 97(9):4666-71.

45. Vinogradov $A D$ : NADH/NAD + interaction with $N A D H$ : ubiquinone oxidoreductase (complex I). Biochim Biophys Acta 2008, 1777(7-8):729-34.

46. Molnar AMA, Pereira-da-Silva L, Macedo DV, Dabbeni-Sala F: Evaluation by blue native polyacrylamide electrophoresis colorimetric staining of the effects of physical exercise on the activities of mitochondrial complexes in rat muscle. Brazilian Journal of sMedical and Biological Researsh 2004, 37(7):939-947.

47. D'Agostino B, et al: Exercise capacity and cytochrome oxidase activity in muscle mitochondria of COPD patients. Respir Med 2010, 104(1):83-90.

48. Raffaello A, Rizzuto R: Mitochondrial longevity pathways. Biochim Biophys Acta 2011, 1813(1):260-8.

49. Powers SK, Jackson MJ: Exercise-Induced Oxidative Stress: Cellular Mechanisms and Impact on Muscle Force Production. Physiol Rev 2008, 88(4):1243-1276.

50. Starnes JWB, Brian D, Olsen, Marissa E: Exercise training decreases rat heart mitochondria free radical generation but does not prevent $\mathrm{Ca}$ 2+-induced dysfunction. Appl Physiol 2007, 102.

51. Starnes JWB, Brian D, Olsen ME: Exercise training decreases rat heart mitochondria free radical generation but does not prevent $\mathrm{Ca}^{2+}$-induced dysfunction. J App/ Physiol 2007, 102(5):1793-1798.

52. Knoop V, et al: Transport of magnesium and other divalent cations: evolution of the 2-TM-GxN proteins in the MIT superfamily. Mol Genet Genomics 2005, 274(3):205-16.

53. Smith GA, et al: The effect of $M g 2+$ on cardiac muscle function: Is CaATP the substrate for priming myofibril cross-bridge formation and $\mathrm{Ca} 2+$ reuptake by the sarcoplasmic reticulum? Biochem J 2001, 354(Pt 3):539-51.

54. Gobatto CA, et al: Maximal lactate steady state in rats submitted to swimming exercise. Comp Biochem Physiol A Mol Integr Physiol 2001, 130(1):21-7.

55. Short KR, et al: Changes in myosin heavy chain mRNA and protein expression in human skeletal muscle with age and endurance exercise training. J Appl Physiol 2005, 99(1):95-102.

56. Bradford MM: A rapid and sensitive method for the quantitation of microgram quantities of protein utilizing the principle of protein-dye binding. Anal Biochem 1976, 72:248-54.

57. Laemmli UK: Cleavage of structural proteins during the assembly of the head of bacteriophage T4. Nature 1970, 227(5259):680-5.

58. Blum $\mathrm{H}$, Beier $\mathrm{H}$, Gross $\mathrm{HJ}$ : Improved silver staining of plant proteins, RNA and DNA in polyacrylamide gels. Electrophoresis 1986, 8:93-99.

59. Gorg A, Postel W, Gunther S: The current state of two-dimensional electrophoresis with immobilized pH gradients. Electrophoresis 1988, 9(9):531-46.

60. Shevchenko A, et al: In-gel digestion for mass spectrometric characterization of proteins and proteomes. Nat Protoc 2006, 1(6):2856-60.

61. Henzel WJ, et al: Identifying proteins from two-dimensional gels by molecular mass searching of peptide fragments in protein sequence databases. Proc Natl Acad Sci USA 1993, 90(11):5011-5.

62. Gay $S$, et al: Peptide mass fingerprinting peak intensity prediction: extracting knowledge from spectra. Proteomics 2002, 2(10):1374-91.

63. Holloway KV, et al: Proteomic investigation of changes in human vastus lateralis muscle in response to interval-exercise training. Proteomics 2009, 9(22):5155-74.

doi:10.1186/1472-6793-12-11

Cite this article as: Rocha et al:: High molecular mass proteomics analyses of left ventricle from rats subjected to differential swimming training. BMC Physiology 2012 12:11. 